\title{
RESEARCH OF SURFACE WATER QUALITY, TREATING IT IN RETENTION PONDS
}

\author{
Stefanija Misevičienė \\ Aleksandras Stulginskis University, Lithuania \\ stefanija.miseviciene@asu.lt
}

\begin{abstract}
Surface water runoff, formed in the company areas due to changing wastewater discharge and pollution fluctuations can be treated in retention ponds. Pollutants, released into the ponds, mineralize during complex natural biochemical processes in the aquatic environment. The paper presents the long-term observation data $(2004-2016 \mathrm{~m}$.) on the purification of surface wastewater, formed in the company's production territory, in retention ponds. The aim of this work is to identify surface wastewater purification efficiency in retention ponds. Wastewater samples were taken before and after biological treatment. The samples were investigated in the Chemical Analysis Laboratory of the Water Research institute of Lithuania University of Agriculture. Biochemical oxygen demand $\left(\mathrm{BOD}_{7}\right)$ was determined with titrometric method, suspended solids (SS) - with gravimetric method, having filtered the substance through a mid-thickness filter. Concentrations of oil pollutants were determined with the help of a spectrophotometric device of infrared rays IKAN-1 in the Analytical Department of Agrochemical Study Center of Lithuanian Agricultural Institute.

Although the suspended solids, $\mathrm{BOD}_{7}$, and oil hydrocarbon concentrations, released into the natural environment, were below the MAC when they are collected from the company's production areas, they are often contaminated; therefore, it is necessary to treat them. The purification efficiency of researched materials was satisfactory and reached 61,64 and $91 \%$.
\end{abstract}

Key words: surface wastewater, retention ponds, polluting materials.

\section{Introduction}

Surface wastewater management is still relevant, because surface wastewater transmits various contaminants from stationary pollution sources into the environment. As urban areas grow, the collected surface wastewater levels increase as well. Most urban surface wastewater is discharged untreated, significant amounts of wastewater reach surface water bodies from diffuse pollution sources. With the growing influx of vehicles, intensifying construction, conducting road maintenance, surface wastewater contamination increases (Göbel et al., 2006; Paul Meyer, 2008; Yang et al., 2010; Rentz et al., 2012). When assessing the period since 2004, it can be claimed that the key pollutants have dropped significantly: $\mathrm{BDS}_{7}$ decreased by $55.5 \%$, suspended solids $-30.7 \%$, total nitrogen $-38.5 \%$, total phosphorus $-61.5 \%$, oil and its products $-51.4 \%$. The crucial factor in the depletion of the amount of emitted pollutants was a more effective cleaning of sewage treatment systems (Mereškevičienè, 2015).

According to the data from the Environmental Protection Agency, during 2013 there was about 52.9 $\mathrm{m}^{3}$ of surface (rain sewerage) wastewater discharged into surface water bodies. Surface wastewater from areas, where there are no sources of pollution to water environment with harmful substances - parks, pedestrian zones, lawns, playgrounds, etc. - is discharged into water bodies without treatment. Such runoff accounted for $87.5 \%$ of all surface water in 2013. The most commonly treated surface wastewater comes from industrial companies, waste treatment facilities, gas stations' areas. Treated wastewater constituted $12.5 \%$ of all surface wastewater. Of these,
$89.4 \%$ of wastewater was treated to the required standards, $10.6 \%$ was discharged insufficiently treated (Mereškevičienè, 2015).

The worst water quality is close to the pollution sources. As it can be difficult to quickly reach the permissible limits in these areas, they have a longer transition period - the water near the sources of pollution will have to comply with the requirements of the directive by 2018. Meanwhile, by 2025 any direct discharge of pollutants into surface waters must be discontinued.

To protect the natural environment against pollution, the surface wastewater management regulation adopted on the $2^{\text {nd }}$ April 2007 by the Lithuanian Minister of the Environment, established the environmental requirements for surface wastewater collection, treatment and discharge. This Regulation applies to all persons managing the areas on which surface wastewater forms or may form, persons who are preparing planning documents of such territories, construction projects, who are currently planning surface wastewater management systems, who are planning to discharge or are discharging surface wastewater runoff to the environment or to waste water treatment systems belonging to other persons, as well as institutions regulating and controlling surface wastewater management.

Surface wastewater management regulations contain concentrations of not only the most important pollutants, but also of other materials, harmful to the environment. According to it, the surface wastewater, collected from the company's production area, can be discharged into the natural environment only when the instantaneous and average 
annual maximum allowable concentrations are as follows: suspended solids 50 and $30 \mathrm{mg} \mathrm{l}^{-1}$, $\mathrm{BOD}_{7}-$ 57.5 and $28.75 \mathrm{mg} \mathrm{l}^{-1} \mathrm{O}_{2}$, oil hydrocarbons -7 and $5 \mathrm{mg} \mathrm{l}^{-1}$, respectively (Surface..., 2007).

The observation of surface wastewater management in the meat processing plant is being carried out since 2004. The company's manufacturing and domestic wastewater is supplied to Kedainiai town water treatment plants, and the surface wastewater from the industrial area is collected by sewer networks and treated in a biological treatment ponds.

Technically sound vehicles are used for animal transportation, from which the pollution from oil products is possible only in case of an accident, and the production area is tidy: in winter snow is ploughed from the asphalt coating, in spring - sand is swept away.

The aim of the research is to identify surface wastewater treatment efficiency in biological treatment ponds. The study tasks of the research: to determine the concentrations of pollutants formed in the surface wastewater in the company's production area before treatment and to determine the concentrations of pollutants in the surface wastewater that is being released to the environment.

\section{Materials and Methods}

Company's production area is bordered by roads from the north and the west while from the east and south - by arable land. Buildings and communications' layout of the production area, occupying 10.6 hectares, is shown schematically in Figure 1.

Surface wastewater collected from the company's territory is flushed in closed collectors into the treatment plant. The treatment equipment is made up of oil sludge trap and a two-stage biological treatment pond. The efficiency volume of the oil dirt pollutants trap $-158 \mathrm{~m}^{3}$, biological pond $-1500 \mathrm{ml} \mathrm{m}^{3}$. The latter has two stages $-1 / 3$ of the pond (in the wastewater inflow area) is $1.8 \mathrm{~m}$ deep and is used for dust and sand deposition, $2 / 3$ of the pond is only $0.7 \mathrm{~m}$ deep and is planted with aquatic plants (bulrush).

Water analysis was done by the Chemical Analysis Analytical Laboratory of the Water Resource

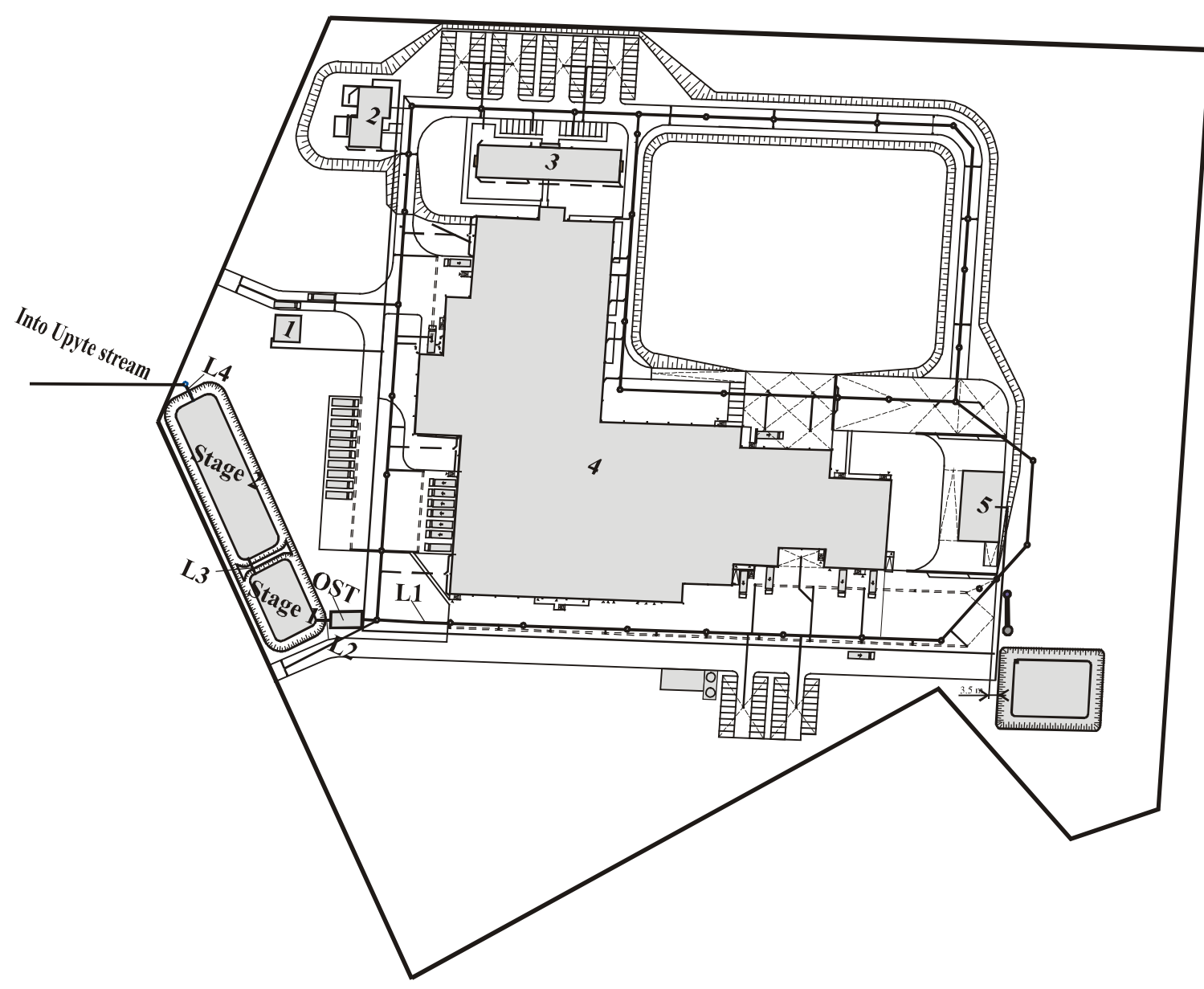

Figure 1 . The scheme of company territory: 1 - watcher's building, 2 - flats of the enterprise, 3 - premises of the administration, 4 - buildings of production, 5 - washing premises of cattle's carriages, L1...L4 - surface water network, Stage $1 \ldots$ Stage 2 - biological pond; OST - oil sludge trap. 
Engineering Institute of Aleksandras Stulginskis University. Suspended solids in the samples were identified by filtration through glass fibre filters, $\mathrm{BOD}_{7}$ - the oxygen content difference was calculated after 7 days of incubation, oil products - identified by the infrared spectrophotometric method with IKAN1. The analysis was carried out in the Agrochemical Research Laboratory of Lithuanian Research Centre for Agriculture and Forestry.

The efficiency of surface wastewater treatment is expressed as a percentage of the decrease in pollutant concentration in relation to the primary concentration. Surface wastewater treatment efficiency is calculated using the following formula:

$$
E=\frac{C-C_{0}}{C} \cdot 100
$$

where $\mathrm{E}$ - treatment efficiency \%;

$\mathrm{C}$ - pollutant concentration in surface wastewater, collected from company's production area $\mathrm{mg} \mathrm{l}^{-1}$;

$\mathrm{C}_{\mathrm{o}}$ - pollutant concentration in surface wastewater, released to the environment $\mathrm{mg} \mathrm{l}^{-1}$.

Statistical analysis of the data was performed using the computer program Excel.

\section{Results and Discussion}

The years with the highest precipitation were 2007, 2009, 2010, 2012 and 2016, when it reached $118,128,128,128$ and $127 \%$ of the climate normals, respectively. The lowest precipitation was in 2005, 2006 and $2015-83,83$ and $86 \%$ of the climate normals respectively. Precipitation level in 2004, 2008, 2011, 2013 and 2014 was broadly in line with the norm and accounted for 98, 101, 101, 95 and $99 \%$ climate normals respectively. During the entire research period, the average air temperature was higher than the climate normals, with the exception in 2005, 2010 and 2012 when it was lower than climate normals $-0.3,-0.8$ and $-0.3{ }^{\circ} \mathrm{C}$ respectively. The warmest years were in 2008 and 2015 , because the average daily air temperature was $1.5^{\circ} \mathrm{C}$ higher than the climate normals (Fig. 2).

The key indicators of the surface water pollution are suspended solids, $\mathrm{BOD}_{7}$ and oil products' concentrations. According to $\mathrm{Li}$ et al. (2014), suspended solids, forming sediments in surface water, have the greatest impact on water quality. Part of suspended solids settles as the wastewater flow rate reduces. During the research period, the higher concentration values of suspended solids in the wastewater runoff from the company's territory were most often established at the beginning of operation of the company, when there was a gravel road near the company. A large car traffic used to cause a cloud of dust, which would settle in the company's territory. After precipitation, the dust was being carried away with the storm wastewater to the collection system. In $2004-2007$ the average concentrations of these substances from the company's production area were higher than the maximum allowable concentration and ranged from 38.3 to $60.8 \mathrm{mg} \mathrm{l}^{-1}$, but the highest instantaneous concentrations ranged from 104 to $220 \mathrm{mg} \mathrm{l}^{-1}$ (Fig. 3).

Since 2008, after the asphalt road had been constructed, the situation due to suspended solids in rain wastewater improved significantly. Average concentration values of these substances have never exceeded the MAC until 2016, except some instantaneous concentrations in 2009, 2012, 2014 and 2016 that were 1.6, 1.3, 1.7 and 1.6 times higher than MAC, respectively. However, after the wastewater went through all the treatment steps, the quantity of suspended solids has decreased and, according to

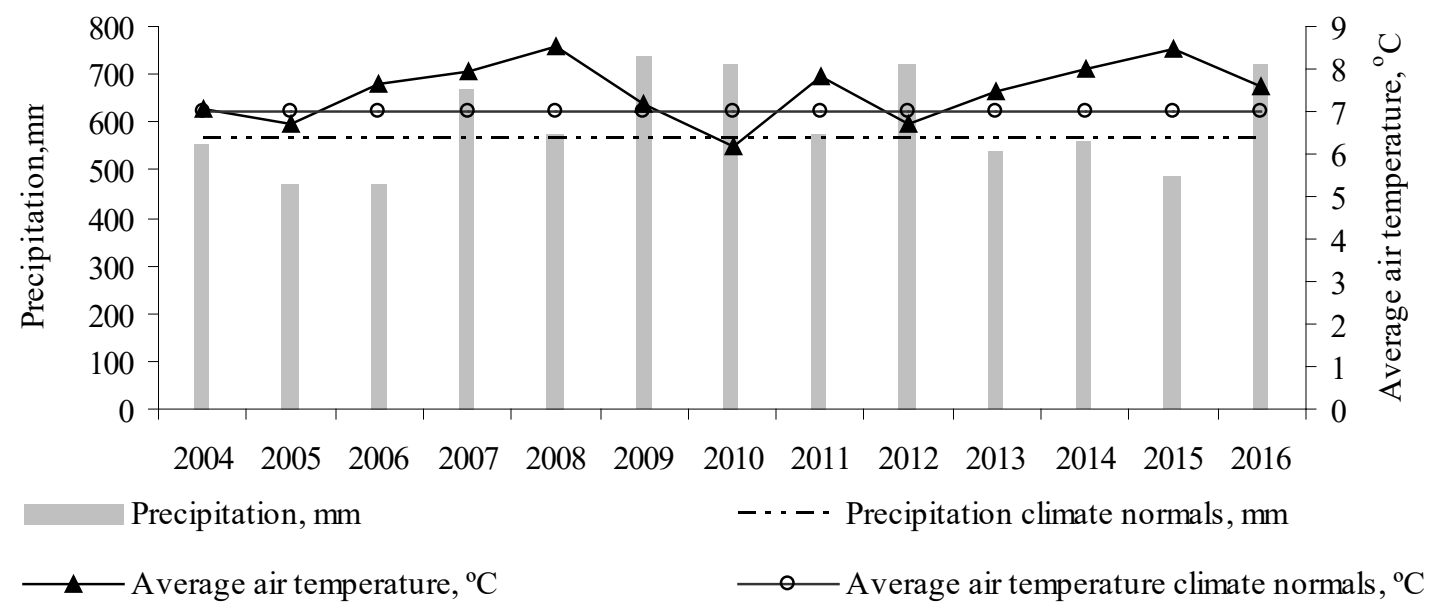

Figure 2. Meteorological conditions. 


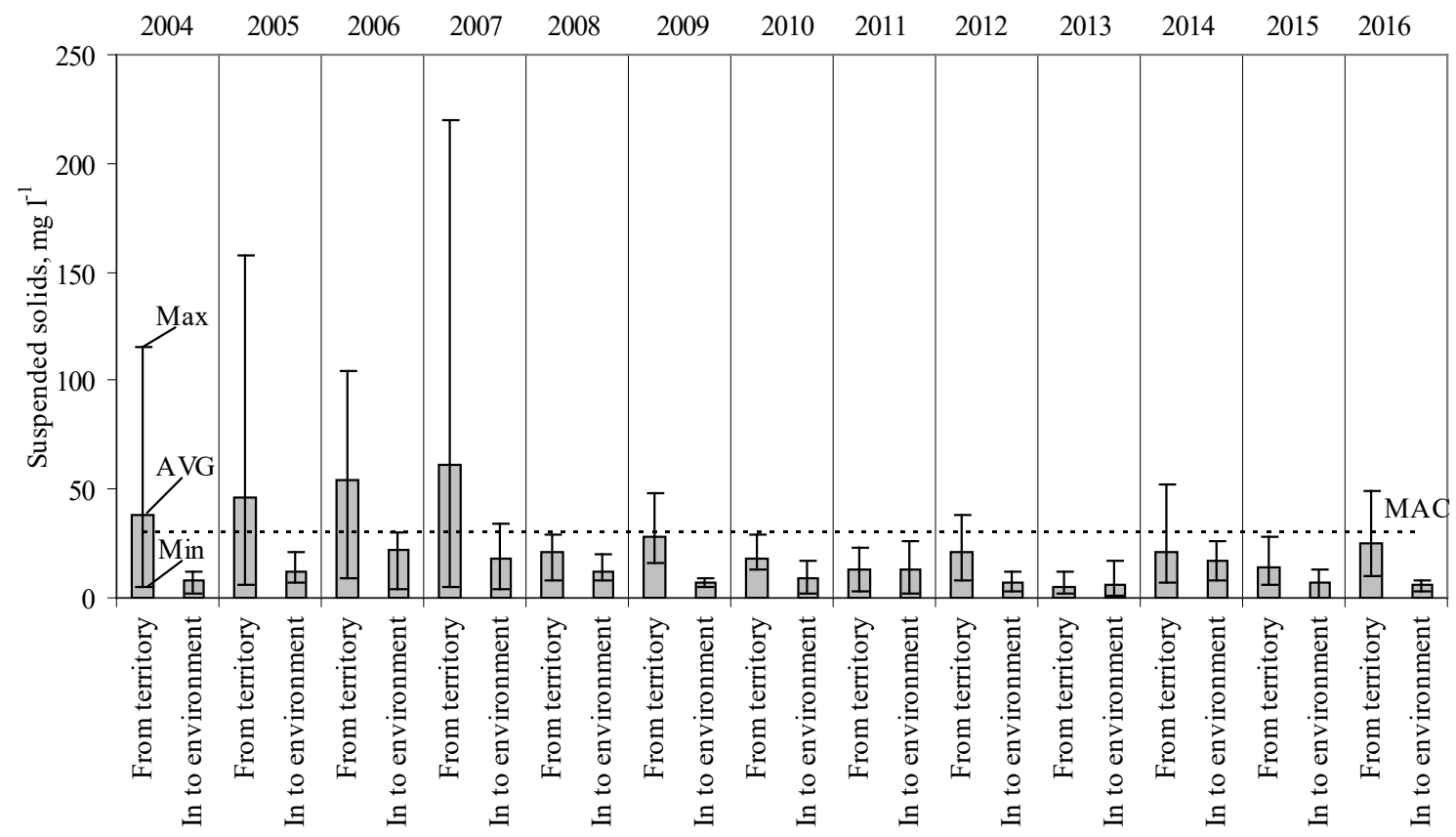

Figure 3. Fluctuations of suspended solids in surface water.

the aforementioned regulation, the average annual concentration of these substances that is released to the natural environment with the surface wastewater was $10.9 \mathrm{mg} \mathrm{l}^{-1}$ and did not exceed $30 \mathrm{mg} \mathrm{l}^{-1}$.

Surface wastewater pollution by organic substances is indicated by the $\mathrm{BOD}_{7}$ rate. During the research period, the values of this indicator in the surface wastewater runoff from the company's territory were higher than the MAC in 2006, 2007, 2011, 20122015 and 2016 - 36, 187, 55.9, 33.4, 185.6, $63.3 \mathrm{mg} \mathrm{l}^{-1}$, respectively (Fig. 4).

Surface rain wastewater, after going through all treatment stages, was cleaned from organic pollution, because the $\mathrm{BOD}_{7}$ concentrations in the wastewater that is released to the environment were determined to be low, as even the highest concentrations were 1.4 - 1.6 times lower than the maximum allowable instantaneous concentration of this indicator.

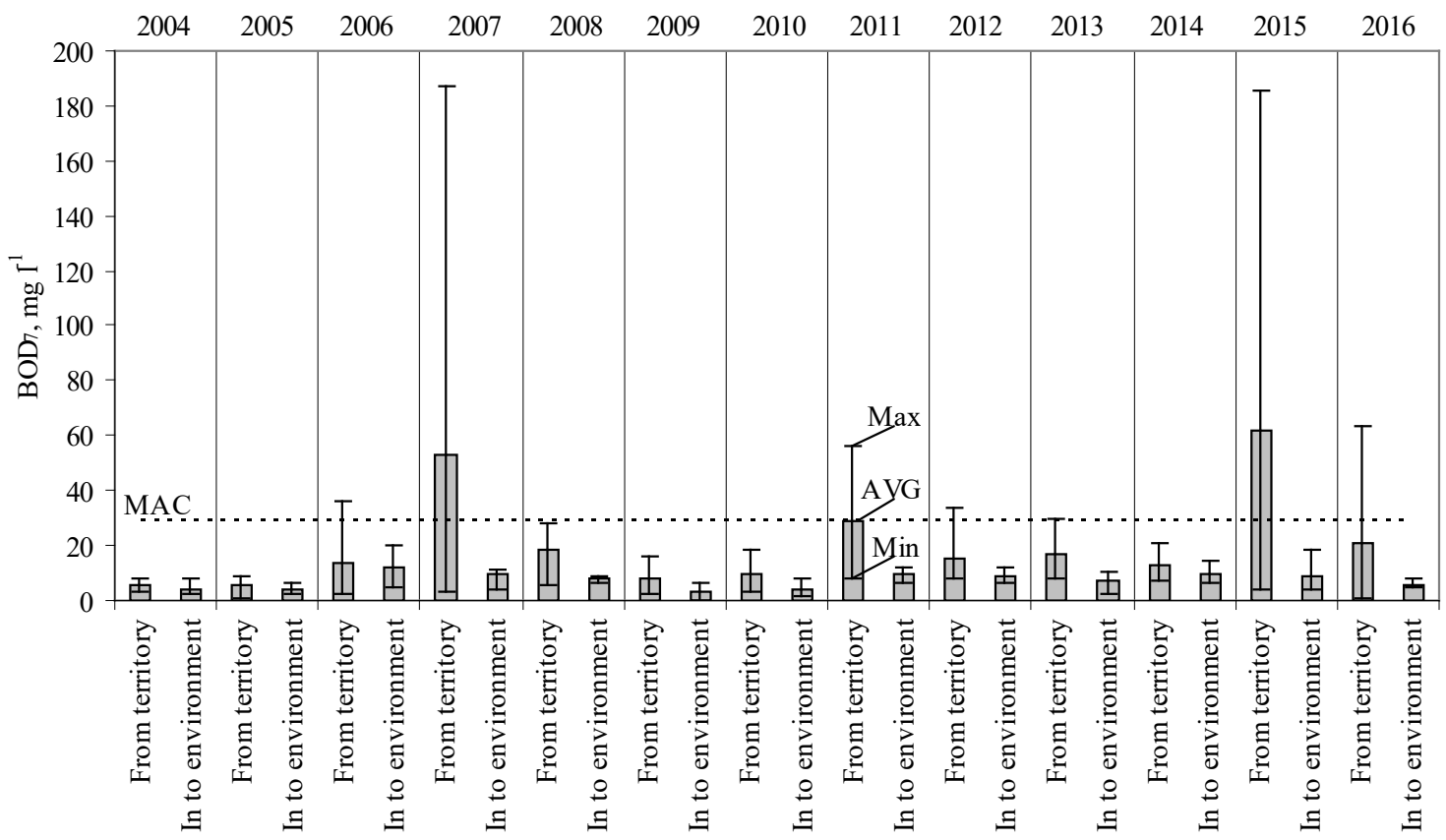

Figure 4. Fluctuations of $\mathrm{BOD}_{7}$ in surface water. 


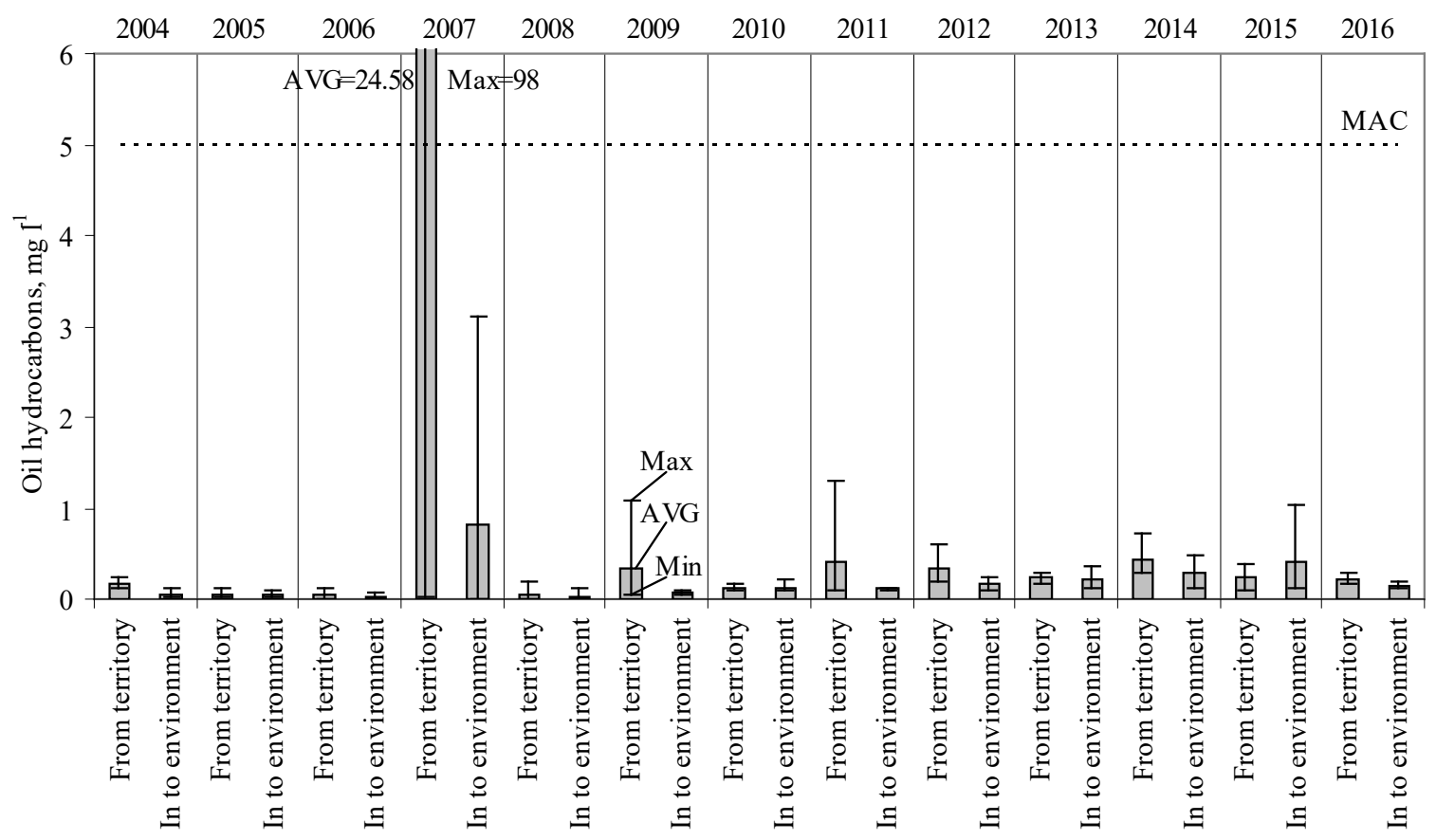

Figure 5. Fluctuations of oil hydrocarbons in surface water.

Effectiveness indicators of surface wastewater treatment

Table 1

\begin{tabular}{|c|c|c|c|c|c|c|c|}
\hline \multirow{2}{*}{ Indices } & \multicolumn{6}{|c|}{ Concentration, $\mathrm{mg} \mathrm{l}^{-1}$} & \multirow{2}{*}{$\begin{array}{c}\text { The average } \\
\text { treatment } \\
\text { efficiency \% }\end{array}$} \\
\cline { 2 - 7 } & \multicolumn{3}{|c|}{ Before treatment } & \multicolumn{3}{|c|}{ In to environment } \\
\cline { 2 - 7 } & Min & Max & Average & Min & Max & Average & 61 \\
\hline $\mathrm{SS}$ & 1.6 & 220 & 28.2 & 0.5 & 34 & 11.1 & 64 \\
\hline $\mathrm{BOD}_{7}$ & 0.55 & 187 & 20 & 0 & 20 & 7.3 & 91 \\
\hline Oil hydrocarbons & 0 & 98 & 2.1 & 0 & 3.1 & 0.2 & 61 \\
\hline
\end{tabular}

The literature suggests that $\mathrm{BOD}_{7}$ concentration in wastewater can be reduced by growing algae (Abdel-Raouf et al., 2012); however, the research shows that bulrush that was grown in the shallower area of the pond also reduced the values of this indicator.

Water bodies are polluted excessively by oil and its products. However, over a longer period of time this pollutant is decomposed by microorganisms (Das \& Chandran, 2010). Higher oil hydrocarbon concentrations during the observation period were determined in the wastewater from the company's territory in 2007 and were as high as $98 \mathrm{mg} \mathrm{l}^{-1}$, which is even 19.6 times higher than the MAC. However, this was an incidental case, as there were construction works being carried out on the company territory using faulty equipment. After the wastewater treatment, the average concentration of oil hydrocarbons decreased to $0.82 \mathrm{mg} \mathrm{l}^{-1}$, and the highest value was $3.1 \mathrm{mg} \mathrm{l}^{-1}$, which is respectively 6.1 and 1.6 times lower than MAC (Fig. 5).
In other years of research, oil hydrocarbon concentrations fluctuated in a small range and the maximum was observed in 2009, 2011 and 2015 - 4.6, 3.8 and 4.8 times lower than the MAC, respectively.

The concentrations of polluting substances in surface wastewater, after passing through biological ponds, were significantly lower than the concentrations referred in the surface wastewater management regulation. On average, during the observation years, the concentrations of suspended solids, $\mathrm{BOD}_{7}$ and oil hydrocarbon, which have passed through the ponds, have decreased by 61,64 and $91 \%$ and were below the MAC (Table 1).

\section{Conclusions}

1. It was found that the company's surface wastewater is mostly polluted by suspended solids, because during the research period, the average pollution in the water from the company's territory was determined to be $28.2 \mathrm{mg} \mathrm{l}^{-1}$. However, after the treatment stages, the suspended solids decreased 
by $61 \%$, i.e. to $11.1 \mathrm{mg} \mathrm{l}^{-1}$. This concentration conforms to the environmental requirements for the surface wastewater that is discharged into the environment.

2. $\mathrm{BOD}_{7}$ concentrations in the water discharged into the natural environment, were very low and did not reach the maximum allowable instantaneous concentrations. The efficiency of wastewater treatment from $\mathrm{BOD}_{7}$ pollution was $64 \%$.

3. The amount of oil hydrocarbons in wastewater was also found to be low - the average concentration of $2.1 \mathrm{mg} \mathrm{l}^{-1}$. The average concentrations of this product in the wastewater that is discharged into the natural environment, during the period were $0.2 \mathrm{mg} \mathrm{l}^{-1}$, i.e. 25 times lower than the MAC.

4. The research has shown that in some cases rainwater runoff, collected from the company's production area is contaminated; therefore, it is important to treat it in pursuit of a better ecological status of streams' water.

\section{References}

1. Abdel-Raouf, N., Al-Homaidan, A.A., \& Ibraheem, I.B.M. (2012). Microalgae and wastewater treatment. Saudi J Biol Sci. 19, 257 - 275. DOI: 10.1016/j.sjbs.2012.04.005.

2. Das, N., \& Chandran, P. (2010). Microbial Degradation of Oil Hydrocarbon Contaminants: An Overview. Biotechnol Res Int. 2011, 13, DOI: 10.4061/2011/941810.

3. Jang, Y.C., Jain, P., Tolaymat, T., Dubey, B., Singh, S., \& Townsend, T. (2010). Characterization of roadway stormwater system residuals for reuse and disposal options. Sci Total Environ. 408, 1878 - 1887. DOI: 10.1016/j.scitotenv.2010.01.036.

4. Göbel, P., Dierkes, C., \& Coldewey, W.G. (2007). Storm water runoff concentration matrix for urban areas. J Contam Hydrol. 91, 26 - 42. DOI: 10.1016/j.jconhyd.2006.08.008.

5. Li, C., Liu, M., Hu, Y., Gong, J., Sun, F., \& Xu, Y. (2014). Characterization and first flush analysis in road and roof runoff in Shenyang, China. Water Sci Technol. 70 (3), 397 - 406. DOI: 10.2166/wst.2014.203.

6. Mereškevičienè, I. (2015). Aplinkos būklè 2014. Tik faktai. (Environment condition 2014. Only facts.) Vilnius: Lututè. (in Lithuanian).

7. Paul, M.J., \& Meyer, J.L. (2008). Streams in the Urban Landscape. In Marzuluff, J., Shulenberger, E., Endlicher, W., Alberti, M., Bradley, G., Ryan, C., Simon, U., \& ZumBrunnen, C. (Eds), Urban Ecology (pp. 207 - 231). New York: Springer. DOI: 10.1007/978-0-387-73412-5_12.

8. Paviršinių nuotekų tvarkymo reglamentas. LR Aplinkos ministro $200 \overline{7} \mathrm{~m}$. balandžio 2 d. įsak. Nr.D1193, (Surface wastewater management regulation. The order of the Minister of Environment No. D1-193) Valstybès žinios, 2007, No. 42-1594. (in Lithuanian).

9. Rentz, R., \& Öhlander, B. (2012). Urban impact on water bodies in the Luleå area, northern Sweden, and the role of redox processes. Hydrol Res. 43 (6), 917 - 932. DOI: 10.2166/nh.2011.167. 